https://helda.helsinki.fi

\title{
Kantian Antitheodicism
}

\section{Pihlström, Sami}

de Gruyter

2019

Pihlström , S 2019 , Kantian Antitheodicism . in V Waibel, M Ruffing \& D Wagner (eds), Natur und Freiheit : Akten des XII. Internationalen Kant-Kongresses . de Gruyter , Berlin , pp. 2895-2904 . https://doi.org/10.1515/9783110467888-291

http://hdl.handle.net/10138/310749

https://doi.org/10.1515/9783110467888-291

acceptedVersion

Downloaded from Helda, University of Helsinki institutional repository.

This is an electronic reprint of the original article.

This reprint may differ from the original in pagination and typographic detail.

Please cite the original version. 


\section{KANTIAN ANTITHEODICISM}

Sami Pihlström (Faculty of Theology, University of Helsinki, Finland)

E-mail: sami.pihlstrom@helsinki.fi

\section{Introduction: theodicism in the philosophy of religion}

The main paradigm of the problem of evil in contemporary analytic philosophy of religion is theodicism, by which I refer to all views that regard theodicy as a requirement any acceptable theism must meet. The theodicist can even be an atheist, if s/he concludes that God does not exist (or that there is no justification for theism) because the theodicy desideratum cannot be fulfilled. Also those offering a mere "defense" - instead of a theodicy proper - can be regarded as theodicists in the sense that they still seek to account for God's justice by arguing that, for all we know, God could have morally good reasons to allow the world to contain evil. Accordingly, the theodicist project in the philosophy of religion is not restricted to thinkers who defend explicit theodicies, such as Richard Swinburne (advocating a version of the "free will theodicy") and John Hick ("soulmaking theodicy"), but includes those who offer us mere defenses as well as those, such as Marilyn McCord Adams, who reject all standard theodicies as unacceptable instrumental justifications of evil while appealing to a post-mortem metaphysical compensation for the injustices of the world. ${ }^{1}$

The Kantian criticism of theodicism is highly relevant to these contemporary discussions. I will outline the argument of Kant's "theodicy essay" and apply its antitheodicism to the theodicy debate, arguing that a Kantian "authentic theodicy" is an antitheodicy and that we should follow Kant in rejecting theodicies for not only intellectual but also ethical reasons. ${ }^{2}$

\section{Kant's theodicy essay}

Kant's "Über das Misslingen aller philosophischen Versuche in der Theodicee", usually does not get the kind of attention that Kant's views on radical evil do. ${ }^{3}$ As Richard Bernstein notes, Kant's

\footnotetext{
${ }^{1}$ See, e.g., Adams, Marilyn McCord: Ignorance, Instrumentality, Compensation, and the Problem of Evil. In: Sophia 52 (2013), 7-26; Hick, John: Evil and the God of Love. Rev. ed. San Francisco 1978; van Inwagen, Peter: The Problem of Evil. Oxford 2006; Plantinga, Alvin: God, Freedom, and Evil. Grand Rapids, MI 1977; Swinburne, Richard: Providence and the Problem of Evil. Oxford 1998.

${ }^{2}$ The argument of this paper is much more comprehensively developed in my joint work with Sari Kivistö; see Kivistö, Sari and Pihlström, Sami: Kantian Anti-Theodicy and Job's Sincerity. Forthcoming in: Philosophy and Literature 40:2 (2016); Kivistö, Sari and Pihlström, Sami: Kantian Antitheodicy: Philosophical and Literary Varieties. Basingstoke, forthcoming 2016. Cf. also Pihlström, Sami: Taking Evil Seriously. Basingstoke 2014.

${ }^{3}$ MpVT (AA 08) was first published in Berlinische Monatsschrift, September 1791, 194-225; I will cite the English translation, "On the Miscarriage of all Philosophical Trials in Theodicy". In: Kant, Immanuel: Religion and Rational Theology. Transl. and eds by Allen W. Wood and G. Di Giovanni, Cambridge 1996, 20-37. For secondary literature, see, e.g., Brachtendorff, Johannes: Kants Theodizee-Aufsatz-Die Bedingungen des Gelingens philosophischen Theodizee. In: Kant-Studien 93 (2002), 57-83; Galbraith, Elizabeth C.: Kant and "A Theodicy of Protest”. In: Kant and the New Philosophy of Religion. Eds. Chris L. Firestone and Stephen R. Palmquist, Bloomington 2006, 179-189. As Galbraith notes (182), it was (again) Hume who "awoke Kant from his dogmatic slumbers" regarding theodicy. The theodicy essay is of course a late work; in his pre-critical writings, Kant seems to have favored a Leibnizian theodicy.
} 
rejection of theodicies is a crucial part of his critical philosophy: insofar as theodicies aim at theoretical knowledge about God, they are not merely contingent failures but impossible, given the limitations of human reason; it is by limiting the sphere of knowledge that Kant, famously, makes room for faith. ${ }^{4}$ Kant is "the modern philosopher who initiates the inquiry into evil without explicit recourse to philosophical theodicy", leading the way in attempts to rethink the meaning of evil and responsibility "after Auschwitz". 5

Kant begins by defining theodicy as "the defense of the highest wisdom of the creator against the charge which reason brings against it for whatever is counterpurposive [zweckwidrig] in the world" (MpVT 8:255). Whoever authors a theodicy must prove "either that whatever in the world we judge counterpurposive is not so; or, if there is any such thing, that it must be judged not at all as an intended effect but as the unavoidable consequence of the nature of things; or, finally, that it must at least be considered not as an intended effect of the creator of all things but, rather, merely of those beings in the world to whom something can be imputed, i.e. of human beings" (8:255). Counterpurposiveness can be divided into three categories: (i) the "absolutely counterpurposive, or what cannot be condoned or desired either as end or means", i.e., the "morally counterpurposive", or "evil proper ( $\sin$ )"; (ii) the "conditionally counterpurposive, or what can indeed never co-exist with the wisdom of a will as end, yet can do so as means", i.e., the "physically counterpurposive", or "ill (pain)"; and (iii) a counterpurposiveness regarding "the proportion of ill to moral evil", i.e., "the disproportion between crimes and penalties in the world" (8:256-257). These challenge the "world-author's" or creator's (God's) holiness, goodness, and justice, respectively - the three attributes that in conjunction constitute the "moral concept of God" (8:257). This multidimensional challenge thus puts God on a moral trial.

Kant moves on to consider the theodicies that can be proposed as counterarguments to the criticisms of the creator focusing on the three kinds of counterpurposiveness. First, he distinguishes three ways of countering complaints about the holiness of the divine will. Among these, he first considers the claim that divine wisdom has "totally different rules" from the human one, i.e., "the ways of the most high are not our ways (sunt supris sua iura)" and are thus incomprehensible to us (8:258). He notes: "This apology, in which the vindication is worse than the complaint, needs no refutation; surely it can be freely given over to the detestation of every human being who has the least feeling for morality." (8:258) The mere appeal to divine rules being different from ours turns God into a monster who does not care about morality at all. Secondly, God could be excused from moral evil by maintaining that it "could not be prevented, because founded upon the limitations of the nature of human beings, as finite" (8:258-259). Here the problem is that "the evil would thereby

\footnotetext{
${ }^{4}$ Bernstein, Richard: Radical Evil: A Philosophical Interrogation. Cambridge 2002, 3-4.

${ }^{5}$ Ibid., 4.
} 
be justified, and, since it could not be attributed to human beings as something for which they are to be blamed, we would have to cease calling it 'a moral evil.'" (8:259) Thirdly, it may be suggested that there is indeed moral evil in the world but we human beings are guilty for it, and "no guilt may be ascribed to God, for God has merely tolerated it for just causes as a deed of human beings" (8:259). This leads back to the previous complaint: as God could not prevent such evil without violating other moral ends, human beings cannot be held responsible for this moral evil, as it is grounded in "the essence of things" and "the necessary limitations of humanity" (8:259).

The second set of attempted vindications of God focuses on complaints about divine goodness. The first attempt says that we prefer to be alive to being dead, even if life involves ills and pains; this Kant refutes as mere sophistry $(8: 259)$. According to the second vindication, "the preponderance of painful feelings over pleasant ones cannot be separated from the nature of an animal creature such as the human being", but this leads to the question of "why the creator of our existence called us into life when [life] is not desirable to us" (8:260). The third theodicy in this group refers to our "future happiness", suggesting that we ought to become worthy of our future glory "precisely through our struggle with adversities". Again, this is only something that can be "pretended", but there can according to Kant be no "insight into it". (8:260)

Kant's third group of theodicies addresses divine justice (8:260). Again these come in three versions. The first says that "every crime already carries with it its due punishment" in one's tormented conscience and hence denies that "the depraved go unpunished" (8:261). Here, Kant notes, "the virtuous man lends to the depraved the characteristic of his own constitution" (8:261); clearly, conscience does not seem to torment all wrong-doers. It could, secondly, be maintained that "it is a property of virtue that it should wrestle with adversities [...], and sufferings only serve to enhance the value of virtue" (8:261). The response is that if an end of life "crown[ing] virtue" fails to materialize, the virtuous may have unjustly suffered not in order for her/his virtue to be pure "but because it was pure"; moreover, the possibility that there is something after our "terrestrial life" cannot be regarded as a vindication of divine providence (8:261-262). ${ }^{6}$ The third and final vindication attempt points out that we must in this world judge well-being and ill "merely as the consequence of the use of the human faculties according to the laws of nature", instead of judging them "according to their agreement with supersensible ends" (8:262). Again, the criticism is that this remains "arbitrary" and that we cannot appeal to another future world in which things would be

\footnotetext{
${ }^{6}$ Kant bases the argument on the ethical ground of religion and theology, rather than vice versa: the possibility that virtue will be crowned in the hereafter is, instead of being any vindication, "merely a decree of morally believing reason which directs the doubter to patience but does not satisfy him" $(8: 262)$. The immortality of the soul is a postulate of practical reason (as argued in $\mathrm{KpV}$ ), but as such it cannot be used as a theodicist vindication of God. We must start from morality, instead of starting from theological doctrines such as immortality, and therefore the moral challenge referring to divine justice must be addressed independently of such doctrines.
} 
different; even if we in the end do have moral reasons for religiously believing in such a world, that belief cannot play a role in the argument supporting the justice of God. (8:262)

Having refuted these theodicies, Kant concludes that "[e]very previous theodicy has not performed what it promised, namely the vindication of the moral wisdom of the world-government [or God] against the doubts raised against it on the basis of what the experience of this world teaches" (8:263). However, in order to finally conclude this "trial", it must still be considered whether "our reason is absolutely incapable of insight into the relationship in which any world as we may ever become acquainted with through experience stands with respect to the highest wisdom"; accordingly, a piece of "negative wisdom" must be established by demonstrating that there is a "necessary limitation of what we may presume with respect to that which is too high for us" (8:263). Kant distinguishes between "artistic" and "moral" wisdom, concluding that we can never hope to attain a concept of "the unity in the agreement in a sensible world between [...] artistic and moral wisdom" (8:263). No mortal being can prove "the world-author's moral wisdom", as we lack insight into the ground of the sensible world in a supersensible (intelligible) one (8:264).

Having completed his negative task of refuting theodicies, Kant points out, however, that a theodicy as "an interpretation of nature insofar as God announces his will through it" can be either "doctrinal" or "authentic"; only doctrinal theodicies, philosophical trials constituting "theodicy proper", have been refuted (8:264). What remains is the possibility of an "authentic theodicy" as "the mere dismissal of all objections against divine wisdom" as a "pronouncement of the same reason through which we form our concept of God - necessarily and prior to all experience - as a moral and wise being", that is, of the reason through which God himself becomes "the interpreter of his will as announced through creation" (8:264). This authentic theodicy is an interpretation of "an efficacious practical reason", instead of that of "a ratiocinating (speculative) reason", and it can be regarded as "the unmediated definition and voice of God" (8:264). Here Kant turns to the Book of Job where he claims to find such an authentic interpretation allegorically expressed.

\section{An authentic theodicy - or antitheodicy?}

It could be argued, even by Kant's own lights, that to offer a truly authentic theodicy is to offer no theodicy at all, or even to offer an antitheodicy, because theodicies of any kind are necessarily inauthentic due to being necessarily immoral. Job's friends can, moreover, be seen as analogous to the theodicist writers within contemporary analytic philosophy of religion, set against more honest attempts to deal with the problem of evil we find in post-Holocaust philosophers of religion and political theorists like Hannah Arendt, Hans Jonas, and Richard Bernstein.

God's speech to Job, as Kant notes (8:266), lays out the "inscrutability" of the divinely created world-system, also showing Job its "horrible side" - destructiveness and 
counterpurposiveness. What remains through Job's encounter with God is, Kant emphasizes, Job's honesty and "his faith on morality" (rather than any "morality on faith"): only the former kind of faith based on honesty can be a foundation of "a religion of good life conduct" (8:267). This, admittedly slightly anachronistically, turns Job into a Kantian moral thinker, while representing his friends as exemplifications of the vices of rationalizing theodicies. For the purposes of an authentic theodicy, "sincerity in taking notice of the impotence of our reason" and "honesty in not distorting our thoughts in what we say, however pious our intention" are key virtues (8:267). Sincerity (Aufrichtigkeit), in short, is "the principal requirement in matters of faith" (8:267). While we cannot know for certain whether what we say is true, as we could always be mistaken, we can and must "stand by the truthfulness" (Wahrhaftigkeit) of what we say (8:267). Hence, the moral vices of theodicism are in the end related to one of the worst vices of Kantian ethics - lying (see 8:268-269).

Toward the end of the essay, Kant discusses insincerity - our tendency "to distort even inner declarations before [our] own conscience" - as "in itself evil even if it harms no one" (8:270). He seems to maintain that speculative theodicies are exemplifications of evil in a specific sense: they do not acknowledge the Kantian - and generally Enlightenment - ideal of free, responsible thought. They are therefore revolts (not primarily against God but) against humanity itself, conceived in a Kantian way. The insincerity of theodicism does not recognize the essential human capacity for freedom and responsibility, for the autonomy necessary for morality. Theodicies, then, are failures to think - and in this sense they interestingly resemble what Arendt called the banality of evil. According to her famous analysis of Adolf Eichmann's case, the striking feature of his "banal" evil was an "inability to think". This does not mean that all manifestations of evil are manifestations of banality, but it could entail that the evil of theodicies is at least related to Arendtian banal evil.

While Kant has been regarded (e.g., by Bernstein) as the first philosopher to approach the problem of evil without recourse to theodicy, some interpreters, like Elizabeth Galbraith, do not seem to go far enough in reading Kant as an anti-theodicist. While drawing attention to Kant's criticism of theodicies as insincere failures to acknowledge the necessary limits of human reflection, Galbraith emphasizes Kant's "authentic theodicy" and takes issue with antitheodicism. The sincerity Kant finds in Job points toward an "appropriate [...] religious response to the inadequacy of traditional theodicies", while reminding us that this does not mean that God just is beyond our moral standards: "Believing that God's justice is different from ours would place God beyond moral accountability, a stance Kant could never support. Rather, the point for Kant is that human reason simply cannot fathom the paradox of how a morally ambiguous world is also the result of a wise Creator. For precisely this reason, traditional theodicies fail." ${ }^{\prime 7}$

\footnotetext{
${ }^{7}$ Galbraith, 184-185.
} 
While this is a sincere attempt to acknowledge the limits of human reason in a Kantian-like way, the problem is that it makes Kant sound more like a skeptical theist. The Kantian antitheodicist should not maintain that the "wise Creator" has humanly unknowable reasons for creating and maintaining a "morally ambiguous" world. This is one of the theodicies Kant rejects. This moral ambiguity certainly needs to be recognized, and it is important to connect this insight with the general Kantian theme of "denying knowledge" in order to make room for faith. ${ }^{8}$ Yet, an "authentic theodicy" should leave it open for us whether we are able to maintain such a faith. Thus, Galbraith's conclusion that "a protesting faith is only truly capable of protesting against the injustice in our own lives and the lives of others if it is sustained by a resilient trust in divine justice" ${ }^{\circ}$ is far too strong. This trust is what we may have lost - say, after the Holocaust.

Accordingly, it is difficult to accept Galbraith's conclusion emphasizing Job's endurance: "Kant's treatment of the story of Job transfers all attention entirely from preoccupation with the justification of God to the religious person's manner of enduring evil. I would add, however, that the only resolution to the problem of evil, in this case, Job's innocent suffering, is a personal faith in divine justice. Faith itself is the only theodicy." 10 The problem is not the emphasis on personal faith but the emphasis on divine justice. This formulation still focuses too much on Job's patience (in contrast to his sincerity), failing to acknowledge the sufferer who cannot endure. We should recognize the response of losing one's faith as a (or possibly the only) religiously available response for some individuals in some concrete situations. This is one reason why the theodicist discourse in which the reality of evil appears as empirical evidence against theism is irrelevant to Kantian concerns: the reality of evil does not challenge theism theoretically but challenges our lives in a practical way. Galbraith fails (while Kant succeeds) in trying to deal with suffering that destroys faith. Faith itself need not be the only, or any, theodicy; on the contrary, antitheodicy (only) makes faith possible, even if it yields a destruction of faith.

Susan Neiman emphasizes, in a manner resembling Bernstein, the moral unacceptability or obscenity of theodicies. The issue comes back to the human limitations that prevent us from having any theoretical knowledge about God, or even about morality (which can only be known from the point of view of practical reason). Knowing the connections between moral and natural evils would, according to Neiman's reading of Kant, "undermine the possibility of morality", and therefore solving the problem of evil is not only an impossible but an immoral project. ${ }^{11}$ Job's pseudocomforters actually sin against their righteous friend and truth itself. Neiman's account of Kant goes beyond the mere appeal to the limits of human knowledge and reason:

\footnotetext{
${ }^{8}$ Ibid., 186; cf. KrV BXXX.

${ }^{9}$ Ibid., 186.

${ }^{10}$ Ibid., 187.

${ }^{11}$ Neiman, Susan: Evil in Modern Thought: An Alternative History of Philosophy. Princeton 2002, 69.
} 
So Kant denounced the standard position one might call the theodicy of ignorance. God's standpoint is not our standpoint; His wisdom is incomparable; what may seem to be against our interests may be in fact the best means of realizing them; unlike God, we cannot judge what is best for the whole. It's a view one might think Kant would find congenial, but he attacked it with vehemence [...]. What's wrong with saying that God has ways we cannot understand?

For Kant, even this much knowledge is too much knowledge. To say that God has purposes, though we don't know them, is to say that God has purposes. That's precisely what was in doubt. To assert it a priori is to trade recognition of the reality of suffering for a consolation so abstract it cannot really comfort. ${ }^{12}$

Accordingly, the inscrutability of evil Bernstein and other antitheodicists speak of must not be confused with the any appeal to God's hidden purposes. To admit that evil remains mysterious and inscrutable is not to claim that there are hidden purposes we cannot know. Both are appeals to human finitude, but only the former is morally sincere in a Kantian sense, avoiding the latter's metaphysical speculation with hidden purposes. Indeed, given that the moral law is, for Kant, the ground of religion, not the other way round, it can be argued that the worst thing about theodicies is not that they are blasphemous but that they are immoral. Theodicism goes against our moral duty to treat all human beings never as mere means but also as ends in themselves.

Theodicies are, then, from a Kantian perspective, morally wrong because they overlook our human finitude. We may say that Kant's radical antitheodicism is rooted (recall the etymology of "radical" in the Latin radix, root) in his view of humanity, particularly human finitude. Theodicy, qua immoral, is radically, often banally, evil. 